Marek SEMPACH

Uniwersytet Łódzki

\title{
Wyspecjalizowane agencje marketingowe w działalności rynkowej krajowych organizacji politycznych
}

Niniejszy tekst stanowi próbę zweryfikowania roli wyspecjalizowanych agencji marketingowych $\mathrm{w}$ działalności rynkowej polskich partii politycznych. Został oparty na szerszych obserwacjach autora prowadzonych w zakresie wykorzystania instrumentów marketingu na rynku politycznym. Celem materiału pozostaje ukazanie możliwości uzyskania przez organizacje polityczne przewagi konkurencyjnej poprzez permanentną współpracę z profesjonalnymi firmami doradztwa marketingowego. Punktem wyjścia do rozważań jest koncepcja nowozelandzkiej badaczki marketingu politycznego Jennifer Lees-Marshment zakładająca całkowite zorientowanie rynkowe nowoczesnej organizacji politycznej (ang. Market Oriented Party). Wedle J. Lees-Marshment partia powinna funkcjonować niczym przedsiębiorstwo, nieustannie zaspokajając potrzeby swoich konsumentów-wyborców. Aby to osiagnąć zobligowana jest do permanentnego wykorzystywania instrumentów marketingowych oraz wyspecjalizowanych agencji doradczych. Niniejszy tekst jest próbą odniesienia przemyśleń J. Lees-Marshment oraz ich ewentualnej implementacji na krajowym rynku politycznym.

Działania kampanijne nowoczesnej organizacji politycznej powinny rozpoczynać się od tworzenia zespołu sztabu wyborczego, a więc grupy zajmującej się projektowaniem strategii działań oraz ich późniejszą realizacją. Organizacja sztabu opiera się na pozyskaniu ekspertów z różnych dziedzin, niebędących jednak funkcjonariuszami danej formacji. $\mathrm{Na}$ tym etapie wyłania się również, zwykle na drodze przetargów partnera strategicznego - agencję konsultingowo-marketingową oraz dodatkowo indywidualnych konsultantów politycznych, zajmujących się konstruowaniem planu działań marketingowych i wprowadzaniem ich w życie.

Jednym z pierwszych zadań stojących przed sztabem wyborczym działającym wespół z agencją jest dokonanie wywiadu marketingowego 
realizowanego w oparciu o wszechstronne badania rynku politycznego. Zajmuje się tym agencja marketingowa, aczkolwiek częstą praktyką jest wydawanie zlecenia przeprowadzenia określonych badań niezależnemu ośrodkowi badania opinii publicznej. Wyniki tychże badań spływają następnie do sztabu, który wspólnie z agencją marketingową zajmuje się ich przetwarzaniem w celu przygotowania oferty zgodnej z oczekiwaniami rynku. Badania mają niezwykle szeroki zakres począwszy od analizy nastrojów społecznych, poprzez ocenę poszczególnych formacji politycznych oraz ich polityków, a na oczekiwaniach programowych i wizerunkowych elektoratu kończąc. W celu uzyskania większej wiarygodności wyników badań, sztab oraz agencja dodatkowo wnikliwie analizują aktualną rynkową sytuację polityczną, jak również obowiązujące prawo wyborcze - ordynację wyborczą. Dzięki tym działaniom, rozpoznaje się potencjalne zagrożenia wynikające z nieścisłości prawa, a także uzyskuje się podstawową wiedzę na temat rynkowej konkurencji (pierwotna analiza SWOT). Zdobyta w ten sposób wiedza, zostanie wykorzystana do jak najdoskonalszego opracowania produktu trafiającego bezpośrednio w potrzeby elektoratu, oferując mu korzyści oraz wartości dodane nieproponowane dotychczas przez konkurencję.

Kolejnym etapem działań jest tworzenie oferty z uwzględnieniem oczekiwań i postaw wyborców. W procesie tym uczestniczą wszystkie struktury partii politycznej oraz agencja marketingowa. Konstruowany program polityczny tworzony jest zgodnie z profilem ideologicznym formacji, aczkolwiek przede wszystkim dopasowuje się go do oczekiwań elektoratu, wyróżniając elementy dla niego istotne, na przykład bezpieczeństwo socjalne obywateli czy kwestia ochrony zdrowia. Jako że każdą partię polityczną tworzą ludzie, równolegle konstruuje się sylwetki liderów oraz kluczowych kandydatów formacji. Charakterologicznie dostosowywane są one do pragnień oraz oczekiwań wyborców. Mają również na celu realne odróżnienie od rynkowych konkurentów. Na tej samej płaszczyźnie działań, obok programu politycznego oraz sylwetek liderów partii tworzy się jej system informacji wizualnej. Przewodnie hasło, logo oraz odpowiednio dobrana kolorystyka są wynikiem pracy zewnętrznych specjalistów z takich dziedzin jak językoznawstwo, semantyka oraz grafika. Tworząc system informacji wizualnej partii, należy uwiadomić wyborcom, iż mają oni potrzeby, których wcześniej nie identyfikowali, a które partia chce zaspokoić. Budowane w taki sposób przesłanie będzie zdecydowanie bardziej wiarygodne dla potencjalnych wyborców. 
Warto odnotować, iż na tym etapie prac sztab oraz agencja dysponują wystarczającymi danymi, aby wstępnie inicjować proces formułowania strategii działań marketingowych. Wymaga to opracowania planu biorącego pod uwagę wszystkie czynniki, które mogą być istotne dla właściwego kształtu opracowywanej strategii. Muszą one odpowiadać stawianym celom marketingowym, jak również wynikającym z nich celom reklamowym oraz medialnym.

Dalszy etap działań skupia się na precyzyjnej identyfikacji potencjalnych segmentów wyborczych, jak również wskazaniu właściwych segmentów docelowych. Precyzyjny podział rynku na określone grupy wyborców - segmenty rynku politycznego, daje możliwość dotarcia z przekazem marketingowym do wybranych grup społecznych, bardziej skłonnych do pozytywnej reakcji na tworzony przekaz ${ }^{1}$. Dla osiagnięcia maksymalnej skuteczności prowadzonych działań, należy precyzyjnie dopasować poszczególne elementy marketingu mix do specyfiki wybranych segmentów rynku. Ma to szczególne znaczenie dla agencji marketingowych oraz zatrudnionych w nich konsultantów politycznych, muszą bowiem oni dokładnie określić w jaki sposób należy tworzyć skuteczny plan marketingowy i do jakich wyborców należy go kierować. Aktywności tego rodzaju nie można w żadnym wypadku pominąć. Stymulują one przekaz, który w większym lub mniejszym stopniu wpłynie na zachowania elektoratu w danym segmencie.

Skuteczność segmentacji uzależniona jest od stopnia wiarygodności wyników przeprowadzanych badań oraz ich odpowiedniej interpretacji. Nie bez znaczenia pozostają przyjęte kryteria segmentacji; najczęściej demograficzne jak również psychograficzne, a także odpowiednia metodologia prowadzonych badań; na przykład VALS (Values and Life Styles) czy bardziej kosztowna CHAID (Chi-square automatic interaction detector). Warto nadmienić, iż precyzja dokonanej segmentacji uzależniona jest równolegle od stopnia doświadczenia agencji zewnętrznej w zakresie prowadzonych badań marketingowych. Najczęściej agencje typu „Full Service” posiadają odpowiednie doświadczenie wyniesione z kampanii realizowanych na rynku przedsiębiorstw. Skuteczność metodologii zaimplikowanej z tegoż rynku, znacznie gorzej sprawdza się w wymiarze politycznym. Formacje partyjne, podejmując się zatem

1 P. Kotler, N. Kotler, Generating Effective Candidates Campaigns ad Causes, Handbook of Political Marketing, Sage Publications, London 1999, s. 9. 
tworzenia nowej marki oraz stopniowego budowania jej wizerunku, powinny dokonać wyboru odpowiedniej agencji marketingowej, poddając u zarania ewentualnej współpracy weryfikacji jej doświadczenia w zakresie segmentacji lub też z góry założyć wynajęcie dodatkowych specjalistów zewnętrznych w tej dziedzinie. Wiązać to się jednak może z dodatkowymi kosztami, które mogą burzyć napięte budżety formacji politycznych. Dlatego też, najczęściej współczesne partie starają się pozyskać agencje posiadające odpowiednie doświadczenie w szeroko pojętym zakresie marketingu strategicznego. Warto zauważyć, iż w Polsce istnieją tego rodzaju instytucje, aczkolwiek ich rynkowe doświadczenie jest wynikiem działania głównie na rynku przedsiębiorstw.

Kolejnym etapem działań omawianych w niniejszym kontekście jest pozycjonowanie partii na rynku, a więc umiejscawianie jej w strategicznie doskonalszym miejscu niż rynkowa konkurencja. Procedury dokonywane $\mathrm{w}$ tym zakresie realizowane są w ramach współpracy sztabu partii oraz pozyskanej do współpracy agencji. Rozpoczynają się od pogłębionego zweryfikowania silnych, słabych stron, szans i zagrożeń formacji, jak również jej głównych rynkowych konkurentów. Integralnym komponentem pozycjonowania na rynku politycznym jest równolegle proces kreowania wizerunku formacji poprzez podkreślanie jej atrybutów takich jak program, poszczególni kandydaci na listach wyborczych czy struktura organizacyjna. Podstawą takowych działań winno być oferowanie przez partię czegoś co do tej pory nie było w sposób wystarczający dostępne dla wyborców ${ }^{2}$. Należy zaoferować elementy zarówno realne, jak i emocjonalne, stanowiące odpowiedź na psychologiczne potrzeby elektoratu. Jednocześnie warto informować rynek o funkcjonalnych składnikach tożsamości formacji politycznej ze względu na konieczność przypominania elektoratowi czym partia wyróżnia się od konkurencji.

Warto zauważyć, iż proces kreowania wizerunku formacji politycznej wykorzystuje znaną z koncepcji marketingu formułę „Jednej propozycji sprzedaży" (ang. Unique Selling Proposition), oznaczającej wyszukiwanie różnic pomiędzy ofertą własnej partii a jej konkurencją. Owo różnicowanie produktu jest często wykorzystywanym w marketingu narzędziem, podkreślającym wyjątkowość formacji wśród jej konkurencji. Jest ono tym

2 C. Varoga, M. Rice, Only the Facts, Professional Research and Message Development, Handbook of Political Marketing, London 1999, s. 244. 
bardziej skuteczne jeśli poparte symplifikacją, zakładającą maksymalne uproszczenie przekazu w celu umożliwienia właściwego rozkodowania treści przez potencjalne grupy wyborców. Im przekaz jest bardziej czytelny, tym sprawniej przebiega proces budowania wizerunku całej partii, której obraz należy maksymalnie dostosowywać do oczekiwań elektoratu. Zgodność kreowanego image z preferencjami wyborców, stymuluje w nich poczucie satysfakcji, co z kolei przekłada się na stopień ich przywiązania do danej marki politycznej oraz właściwą percepcję jej wizerunku ${ }^{3}$.

Dalsze działania skupiają się na ostatecznym formułowaniu oraz wdrażaniu strategii komunikacji z rynkiem. Aktywności te winny opierać się na koordynacji następujących czynników:

- doskonałej organizacji oraz koordynacji działań sztabu oraz zewnętrznej agencji marketingowej;

- właściwym wydatkowaniu nakładów finansowych;

- strategia eskalacyjna,

- strategia uderzeniowa,

- strategia falowa;

- oferowaniu produktu wzbudzającego zainteresowanie ze strony wyborców, różniącego się od oferty konkurencji, stymulującego świadomość elektoratu.

Celem owych działań jest właściwe dobranie instrumentów komunikacji marketingowej, precyzyjnego wyboru mediów reklamy, public relations oraz środków sprzedaży osobistej. Strategia medialna nie może zostać opracowana bez zewnętrznych ekspertów, dysponujących doświadczeniem w tej dziedzinie. Najczęściej są oni pracownikami agencji marketingowych, wyłanianych przez formacje na drodze przetargów. Wyróżnia się jednak sytuacje, w których osoby takie stanowią indywidualne podmioty gospodarcze oferujące usługi partiom politycznym. Ma to jednak miejsce głównie na rynkach, gdzie formacje nie korzystają w pełni z ofert agencji typu „Full Service” skłaniając się ku selektywnemu doborowi podwykonawców komunikacji marketingowej. Na rynkach najbardziej rozwiniętych, osoby tworzące strategię kreatywną kampanii wywodzą się z tej samej agencji co osoby planujące kampanię w mediach. Stanowi to wynik nie tylko skuteczniejszego zarządzania kampanią (oszczędno-

3 Ibidem, s. 252. 
ści), ale również przyczynia się do doskonalszej koordynacji wszelkich działań realizowanych $\mathrm{w}$ postaci media planu. Zawiera on precyzyjne informacje określające wybrane do kampanii nośniki reklamy, formaty reklam, daty i miejsca emisji, koszty emisji oraz parametry medialne, jakie kampania powinna osiagnąc ${ }^{4}$. Akceptacja przez partię media planu oznacza przejście do realizacji kampanii reklamowej w tym produkcji reklam, zakupu czasu reklamowego, powierzchni reklamowej i dostarczeniu odpowiednim mediom właściwych materiałów. Warto zaznaczyć, iż w przypadku gdy partia korzysta z usług agencji marketingowej typu „Full Service”, wszelkie czynności dokonywane w zakresie realizacji mediów (scenariusz spotu, podkład muzyczny, storyboard, przetarg na producenta spotu, zdjęcia, projekt graficzny), przejmuje na siebie sama agencja, przedstawiając partii gotowe rozwiązania do akceptacji. Należy nadmienić, iż w warunkach krajowych, partie samodzielnie dokonują realizacji mediów (wyłączając produkcję spotów reklamowych), co wiąże się z dodatkowymi kosztami (agencje posiadają większe rabaty, gdyż zamawiają więcej czasu i przestrzeni reklamowej) oraz zauważalnie niższą jednorodnością produkowanych komponentów reklamowych.

Wydaje się, iż na rynku politycznym występują następujące czynniki wpływające bezpośrednio na dobór mediów dla klientów z rynku politycznego 5 :

- cele kampanii reklamowej;

- grupa docelowa;

- okres prowadzenia kampanii reklamowej;

- budżet;

- media wybierane przez konkurencję.

Krajowe partie polityczne najczęściej decydują się na budowanie swojego wizerunku poprzez telewizję. Wynika to z faktu, iż medium to dysponuje największym stopniem oddziaływania na elektorat ${ }^{6}$. Działania wizerunkowe realizowane są poprzez:

- spoty reklamowe - komercyjne 30 sekundowe;

4 A. Czarnecki, R. Korsak, Planowanie mediów w kampaniach reklamowych, PWE, Warszawa 2001, s. 22.

5 Opracowanie własne na podstawie A. Czarnecki, R. Korsak, Planowanie mediów w kampaniach reklamowych, PWE, Warszawa 2001, s. 160.

6 J. Blythe, Komunikacja marketingowa, PWE, Warszawa 2002, s. 97. 
- spoty reklamowe - niekomercyjne 5 minutowe, emitowane w telewizji publicznej na mocy ordynacji wyborczej gwarantującej darmowy czas antenowy tylko i wyłącznie w trakcie kampanii wyborczej;

- sponsoring programów;

- konferencje prasowe emitowane przez telewizję;

- uczestnictwo w wybranych programach publicystycznych.

Planowanie reklam w telewizji dokonywane jest w oparciu o badania telemetryczne. Przeprowadzane są one przez agencje marketingowe lub pracujący na zlecenie danej partii dom mediowy. Godziny cieszące się największą popularnością wśród podmiotów politycznych, podobnie jak handlowych, to godziny wieczorne, pomiędzy 18.00 a 22.00 .

Co interesujące, zakup czasu reklamowego przez formacje polityczne w telewizji najczęściej dokonywany jest w następujący sposób:

- bezpośrednio w biurze reklamy danej stacji telewizyjnej (licytacja);

- poprzez usługi świadczone przez dom mediowy;

- poprzez agencję marketingową lub współpracującą z nią agencję reklamową.

Formacje polityczne stale współpracujące $\mathrm{z}$ wybraną agencją marketingową mogą liczyć na znaczne rabaty dochodzące do 15 procent $\mathrm{w}$ cenach czasu reklamowego. Wynika to z przyczyn ekonomicznych; agencja marketingowa realizuje wiele projektów dla różnych klientów w tym samym czasie. Może zatem liczyć na duże upusty w samych stacjach telewizyjnych oraz domach mediowych. Partie polityczne, które samodzielnie realizują swoją politykę medialną wykupują zwykle czas antenowy bezpośrednio w biurze reklamy danej stacji telewizyjnej, często stając do licytacji z innymi reklamodawcami. Jest to rozwiązanie najbardziej kosztowne, aczkolwiek najczęściej dostrzegane w warunkach krajowego rynku politycznego. Partie unikają bowiem kompleksowej obsługi ze strony agencji marketingowych, mylnie zakładając, iż moga poprowadzić całokształt instrumentów komunikacji marketingowej samodzielnie.

Przedstawione powyżej uwarunkowania dotyczące telewizji, znajduja również odzwierciedlenie $\mathrm{w}$ kontekście budowania wizerunku partii z wykorzystaniem reklamy radiowej. Najbardziej pospolitą formą tego typu reklamy są spoty o długości 15 sekund, 30 sekund oraz 3 minut (w przypadku czasu antenowego gwarantowanego przez ordynację wyborczą w radiostacjach publicznych). Zauważa się również inne formy kreacji poprzez sponsoring programów oraz uczestnictwo kandydatów partii $\mathrm{w}$ dobieranych celowo programach publicystycznych. Warto do- 
dać, iż jak wynika z badań, długość spotu radiowego nie ma wpływu na zapamiętywalność marki ${ }^{7}$. Jednakże dłuższe reklamy powodują, iż opinia o reklamowanym produkcie wśród odbiorców jest lepsza. Należy zatem wywnioskować, iż w reklamach typowo wizerunkowych realizowanych na potrzeby formacji politycznych, warto jest stosować dłuższe spoty.

Należy podkreślić, iż produkcja reklamy radiowej obejmuje jedynie warstwę dźwiękową. Jest zatem znacznie tańsza od reklamy telewizyjnej. Szczególną rolę odgrywają tu muzyka oraz słowa, które powinny być konstruowane w prosty a zarazem logiczny sposób. Istotne są również pytania o retorycznym charakterze. Ułatwiają one bowiem kształtowanie postaw słuchaczy.

Producenta spotów wyłania się na drodze przetargów. W przypadku gdy dana formacja na stałe współpracuje $\mathrm{z}$ agencją marketingową, ta zajmuje się organizacją mediów na potrzeby realizowanej strategii. Jest to rozwiązanie wygodne dla partii politycznej, która może skupić się na kwestiach programowych, pozostawiając całokształt problematyki komunikacji marketingowej zewnętrznym specjalistom. Jak wspomniano wcześniej, jest to rozwiązanie kosztowne, aczkolwiek wynikające z funkcjonowania nowoczesnych formacji politycznych zgodnie z orientacją marketingową.

Inną grupę mediów reklamy, wykorzystywanych do budowania wizerunku na rynku politycznym, stanowią prasa codzienna oraz czasopisma. Zaletą tychże nośników jest ich trwałość, której brakuje pozostałym głównym formom komunikacji z wyborcami. Realizowana w nich reklama wizerunkowa, może przyjąć postać modułową (każde wydanie zawiera określoną ilość modułów) lub też zawierać dodatkowe elementy w postaci insertów, wklejek, wszywek czy banderoli. Co oczywiste, w przypadku kampanii wizerunkowych należy unikać zamieszczania reklam partii w prasie o niskiej jakości druku (dotyczy to szczególnie lokalnych dzienników). Może to niekorzystnie wpływać na wizerunek reklamowanej formacji. Charakter oraz image dobieranego tytułu, powinny być brane pod uwagę przy planowaniu jakichkolwiek działań wizerunkowych realizowanych przy użyciu mediów drukowanych. Liczbę potencjalnych odbiorców reklamy szacuje się na podstawie wielkości nakładu oraz wskaźnika czytelnictwa ${ }^{8}$. Dane takie winny być udostępnione partii

${ }^{7}$ A. Czarnecki, R. Korsak, Planowanie mediów w kampaniach reklamowych, PWE, Warszawa 2001, s. 68.

8 J. Blythe, Komunikacja marketingowa, PWE, Warszawa 2002, s. 85. 
przez obsługującą ją agencję marketingową, dom mediowy lub bezpośrednio przez samo wydawnictwo. Niezbędna jest ich wnikliwa interpretacja z uwzględnieniem segmentów rynku, do których ma trafić dana oferta polityczna.

Zamawianie przestrzeni reklamowej w mediach prasowych odbywa się w podobny sposób, jak w przypadku telewizji: bezpośrednio poprzez kontakt z biurem reklamy danej redakcji, poprzez dom mediowy oraz poprzez agencję marketingową lub współpracującą z nią agencję reklamową, zajmującą się równolegle konstrukcją graficzną danej reklamy. W warunkach krajowego rynku politycznego, partie najczęściej samodzielnie konstruują formę graficzną reklamy prasowej, zamawiając jednocześnie przestrzeń reklamową bezpośrednio w redakcjach. Skutkiem takowego stanu rzeczy jest niska spójność reklamy wizerunkowej realizowanej w różnych nośnikach. Jest to aż nadto widoczne w sytuacjach, gdy partia zamawia poszczególne formy komunikacji w odmiennych źródłach. Występuje wtedy niedostateczna koordynacja działań w ramach strategii medialnej; reklama telewizyjna, radiowa i prasowa konstruowane są w różnych miejscach, co skutkuje brakiem ich spójności tak merytorycznej, jak i marketingowej. Kwestia ta stanowi problem we wszystkich dotychczas przeprowadzanych kampaniach wizerunkowych, realizowanych na rynku politycznym w Polsce po 1989 roku.

Budowanie wizerunku z wykorzystaniem instrumentów komunikacji marketingowej odbywa się również poprzez inne dostępne formy: reklamę zewnętrzną (outdoor), reklamę pocztową, internet, telemarketing czy komponenty ambient media. Wydaje się, iż na rynku politycznym szczególną rolę odgrywają wszelkiego rodzaju formy reklamy zewnętrznej. Najbardziej popularne są wielkopowierzchniowe tablice reklamowe - bilbordy o powierzchni dwunastu metrów kwadratowych. Ich projektowanie, druk oraz wynajem miejsca są relatywnie tanie w stosunku do reklamy telewizyjnej. Różnice w kosztach sięgają rzędu 60 procent całej kampanii. Dodatkowym ich atutem jest również możliwość geograficznej segmentacji treści (umieszczenie informacji odpowiadających potrzebom lokalnych społeczności w różnych rejonach kraju). Ma to szczególne znaczenie podczas kreacji wizerunku partii, bowiem przekaz jest dostosowywany do konkretnych potrzeb lokalnej grupy wyborców. Co równie istotne, zamieszczane plakaty mogą być na bieżąco aktualizowane, zgodnie z rozwojem sytuacji na rynku politycznym. Jest to niewątpliwie znaczące w trakcie toczonej negatywnej kampanii wyborczej, kiedy sytuacja zmienia się wyjątkowo dynamicznie. Warto zaznaczyć, iż projek- 
towane $\mathrm{w}$ oryginalny sposób plakaty, zwracają na siebie dodatkową uwagę środków masowego przekazu. Zwykle nie jest to przypadkowe, ma charakter celowy. Powodując bowiem medialne zamieszanie, uzyskuje się skutek w postaci dodatkowego rozgłosu, co niewątpliwie ma wpływ na percepcję wizerunku jakiejkolwiek formacji.

Kreacja wizerunku partii poprzez reklamę zewnętrzną możliwa jest również z wykorzystaniem innych nośników ${ }^{9}$ :

- powierzchnie na ścianach budynków;

- tablice wolno stojące;

- citylighty;

- reklamy na środkach transportu (wewnątrz i zewnątrz);

- mobile (ruchome bilbordy);

- popularne plakaty uliczne;

- reklamy w przestrzeni powietrznej (holowane przez samoloty lub balony);

- reklamy w otoczeniu.

Partia polityczna planująca wizerunkową reklamę zewnętrzną, powinna zwrócić szczególną uwagę na lokalizacje wybranych nośników. Istotna jest ruchliwość danego miejsca, rodzaj ruchu, odległość od drogi lub chodnika, czy też liczba innych tablic znajdujących się w bezpośredniej bliskości ${ }^{10}$.

Formacje polityczne zamawiają zwykle elementy kampanii zewnętrznej nie później niż trzy miesiące przed rozpoczęciem właściwej kampanii wyborczej. Co interesujące, na krajowym rynku politycznym, stosunkowo rzadko wykorzystuje się reklamę zewnętrzną do kreacji wizerunku poza okresem kampanii wyborczej. Jak wspomniano wcześniej, wynika to z niskiej świadomości marketingowej liderów partii, braku permanentnej współpracy z agencjami (zaniechanie doradztwa po okresie kampanii wyborczej) oraz niechęci do stosowania reguł marketingu relacji na rynku wyborczym.

Wizerunkowa reklama zewnętrzna, realizowana na potrzeby klientów z rynku politycznego, powinna zawierać w sobie minimum słów oraz maksimum kompozycji plastycznych przyciągających wzrok wyborców. Projekt oraz same tablice zamawia się bezpośrednio w firmie outdoorowej, u brokera reklamy zewnętrznej, domu mediowym lub w agencji

9 Ibidem, s. 124.

10 A. Czarnecki, R. Korsak, op. cit., s. 76. 
reklamowej. W przypadku, gdy partia stale współpracuje z wyłonioną agencją marketingową, to ona zajmuje się projektowaniem oraz realizacją zlecenia. Krajowe partie, najczęściej jednak decydują się na selektywne działania, polegające na projektowaniu materiału przez własnych grafików oraz późniejszym wykupywaniu przestrzeni u oferentów reklamy zewnętrznej.

Uzupełnieniem działań wizerunkowych, realizowanych w oparciu o tradycyjną reklamę jest (mailing) - reklama pocztowa o charakterze zarówno adresowym, jak i bezadresowym. Medium to jest szczególnie użyteczne wówczas, kiedy partia zamierza dotrzeć do wąskiej grupy docelowej, na przykład mieszkańców wybranych wsi, osiedli czy dzielnic. Drogą pocztową wysyła się ulotki partyjne, listy z prośbą o udzielenie poparcia lub też informacje o kandydatach ubiegających się o mandat w danym rejonie. Niewątpliwą zaletą tej formy kreacji wizerunku jest wysoka elastyczność w kontekście zawartości oraz wielkości materiału reklamowego. Co więcej, przesyłka swoim charakterem może być dostosowywana do każdego rodzaju wyborcy z osobna, a jej żywotność jest stosunkowo długa.

Krajowe formacje polityczne w trakcie kampanii wyborczej coraz chętniej korzystają z prezentowanej właśnie formy reklamy. Każda kolejna realizowana po 1995 roku kampania marketingowa, wiąże się ze wzrostem zainteresowania partii tą formą komunikacji z wyborcami. Wynika to z jej dużej skuteczności, przy zachowaniu relatywnie niskich kosztów. Działania mailingowe ze strony partii politycznych, zazwyczaj realizowane są poprzez wykorzystanie wyspecjalizowanych agencji mailingowych, dysponujących odpowiednimi bazami danych, a także oferujących kompleksowe usługi w tym zakresie. W przypadku jednak, gdy partia polityczna współpracuje na stałe ze świadczącą jej usługi agencją marketingową, to ona właśnie zajmuje się opracowaniem treści zawartości przesyłek oraz ich dystrybucją. W warunkach krajowego rynku politycznego, sytuacja taka nie występuje. Partie polityczne stosują zazwyczaj outsourcing usług marketingowych, korzystając $\mathrm{z}$ ofert różnych oferentów w tym samym czasie.

Warto nadmienić, iż kreacja wizerunku produktu politycznego z zastosowaniem mailingu, może być skuteczna, jeśli wsparta równolegle jest przez działania realizowane przy wykorzystaniu innych instrumentów komunikacji marketingowej. Jak wykazuje bowiem praktyka, wyborcy chętniej sięgają po przesyłki od formacji politycznych, które znają z innych nośników, szczególnie telewizji oraz reklamy zewnętrznej. Na- 
leży zatem podkreślić, iż mailing nie powinien stanowić samodzielnej funkcji kreowania wizerunku, jest bowiem medium wspierającym. Co oczywiste, może być on skutecznie wykorzystywany na rynku politycznym, aczkolwiek jako uzupełnienie procesu budowania image poprzez telewizję, prasę oraz reklamę zewnętrzną. Mailing nigdy nie powinien poprzedzać głównych kampanii wizerunkowych, prowadzonych poprzez uznawane za priorytetowe narzędzia kreacji wizerunku ${ }^{11}$. Uważa się, iż najbardziej stosownym momentem na przeprowadzenie kampanii mailingowej jest trzeci tydzień poprzedzający dzień wyborów. Wizerunek danej formacji jest już na tym etapie znany, natomiast wymaga on jeszcze modelowania w kierunku indywidualnych oczekiwań wyborców.

Interesującym uzupełnieniem procedury kreowania wizerunku partii politycznych jest telemarketing. Podobnie jak zaprezentowany powyżej mailing stanowi medium wspierające działania wizerunkowe. Na rynku politycznym telemarketing przyjmuje następujący charakter:

- wychodzący (pozyskiwanie nowych wyborców, wspieranie wizerunku partii oraz jej kandydatów, budowanie relacji z elektoratem, aktualizacja posiadanych danych);

- przychodzący (obsługa infolinii).

Działania o charakterze wychodzącym najczęściej opierają się na odtworzeniu głosu znanego działacza partii, zachęcającego do głosowania na własną formację. Nagranie takie trwa nie dłużej niż sześćdziesiąt sekund i jest zazwyczaj emitowane w godzinach popołudniowych. Realizacja przebiega zarówno w okresie kampanii wyborczej, jak i po wyborach. Może zachęcać wyborców do uczestnictwa w planowanym wiecu wyborczym danej partii lub też po prostu informować o działaniach formacji oraz jej liderów. Efekty wizerunkowe kampanii wychodzącej są bardziej skuteczne, gdy zamiarem jest utrwalenie wizerunku formacji politycznej. Kreacja image od podstaw w omawianej kwestii nie jest możliwa, bowiem telemarketing jest jedynie narzędziem uzupełniającym proces kreacji wizerunku.

Telemarketing przychodzący opiera się na stworzeniu infolinii, gdzie wyborca zainteresowany daną partią może uzyskać wyczerpujące informacje na jej temat ${ }^{12}$. W Polsce infolinie partii politycznych stosowane

11 D. Kinsey, Political Consulting, Bridging the Academic and Practical Perspectives, Handbook of Political Marketing, London 1999, s. 120.

12 E. Sherman, Direct Marketing, How does it Work for Political Campaigns, Handbook of Political Marketing, London 1999, s. 377. 
są sezonowo, zazwyczaj w trakcie kampanii wyborczej. Po tym okresie, formacje nie inwestują $w$ tenże rodzaj komunikowania $z$ elektoratem, co niewątpliwie wpływa deprymująco na ich wizerunek. Wyborcy bowiem przyzwyczajeni do rozwiązań stosowanych na rynku przedsiębiorstw, oczekują pełnej interaktywności ze strony oferentów politycznych ${ }^{13}$.

Co interesujące, krajowe partie polityczne chętniej stosują telemarketing wychodzący aniżeli przychodzący (kampania parlamentarna 2005). Elementy wychodzące zamawia się w specjalistycznej firmie telemarketingowej, oferującej kompleksową realizację zlecenia (nagranie, dobór adresatów, realizacja). Tymczasem infolinie obsługiwane są zwykle przez osoby zatrudnione bezpośrednio przez sztab wyborczy, a to rodzi problemy związane $z$ udostępnieniem odpowiedniego miejsca oraz niewystarczającym przeszkoleniem konsultantów. Krajowe partie niechętnie zatem wynajmują przychodzące usługi telemarketingowe w firmach zewnętrznych. Zazwyczaj jest to spowodowane brakiem wiedzy o możliwościach zewnętrznych usługodawców w tym zakresie. W przypadku jednak, gdy partia na stałe współpracuje z doradzającą jej agencją marketingową (nie dotyczy Polski), rozwiązania tego typu są jej rekomendowane. Należy spodziewać się, iż w przyszłości ze względu na rozwój technologiczny, działania marketingowe realizowane w oparciu o kontakt telefoniczny będą się pogłębiały, zmierzając w stronę pełnej interaktywności na linii partia polityczna oraz jej wyborcy.

Konkludując, na podstawie ukazanej w niniejszym tekście analizy można sformułować następujące wnioski:

1. Partie polityczne dysponują zbliżonymi wyzwaniami marketingowymi jak przedsiębiorstwa (np. problematyka segmentacji, pozycjonowania, wykorzystania odpowiednich elementów komunikacji marketingowej). Nie wykorzystują jednak potencjału marketingu w takim zakresie jak czynią to firmy. Pewnym rozwiązaniem tego problemu w kontekście oporu partii do pogłębiania współpracy z agencjami byłoby zatrudnianie przez partie indywidualnych specjalistów mogących wskazywać ścieżki wykorzystania narzędzi marketingowych w procesie budowania wizerunku partii. Na podstawie subiektywnych oduczyć autora, właśnie w tej kwestii należy spodziewać się zmian w najbliższym czasie. Indywidualni konsultanci przyczynią się do szerszego wykorzystania marketingu w budowaniu wizerunku partii, a co za tym idzie częstszego zamawiania

13 Ibidem, s. 378. 
usług agencji. Skutkiem tego będzie upowszechnienie stosowania narzędzi marketingowych w procesie budowania wizerunku formacji, aczkolwiek przede wszystkim dzięki indywidualnym konsultantom, a nie agencjom marketingowym.

2. Wydaje się, iż w warunkach krajowego rynku politycznego, wszystkie formacje o statusie parlamentarnym, jak i pozaparlamentarnym, dążą w jak największym stopniu do realizacji działań marketingowych we własnym zakresie. Jest to szczególnie widoczne na etapach analizy ogólnej sytuacji politycznej, tworzenia oferty z uwzględnieniem oczekiwań i postaw wyborców, segmentacji, pozycjonowania oraz kontroli prowadzonych działań. Należy uznać, iż przyczyną takowego stanu rzeczy jest nie tyle brak oferty ze strony agencji, co przekonanie liderów formacji o możliwości samodzielnego realizowania zadań, wynikające z niskiej świadomości marketingowej.

3. Partie polityczne najchętniej korzystają z usług agencji w okresie kampanii wyborczej, zamawiając elementy budowania image poprzez komunikację. Właśnie w tym okresie występuje największe zapotrzebowanie na usługi marketingowe ze strony formacji politycznych. Wówczas najchętniej zamawianymi są wszelkie formy reklamy oraz komponenty Public Relations. Należy nadmienić, iż działania te nie są w pełni skoordynowane, bowiem prowadzone są przez różne agencje, nie współpracujące ze sobą w trakcie kampanii. Tego rodzaju postępowanie ze strony partii politycznych, należy uznać za ułomne bowiem procesy marketingowe wymagają nieustannego monitoringu oraz permanentnej koordynacji działań. Wydaje się, iż sytuacja taka jest pochodną braku specjalistów z zakresu marketingu w sztabach wyborczych partii, co w powiązaniu ze stosunkowo rzadkim wykorzystaniem wiedzy ekspertów agencji prowadzi do nieudanych przedsięwzięć wizerunkowych. Sytuacja taka będzie się pojawiała dopóki, dopóty formacje nie wykorzystają szerzej kompleksowej obsługi agencji lub też nie zatrudnią wykwalifikowanych i kompetentnych niezależnych marketerów.

4. Kampanie wyborcze na polskim rynku politycznym nie toczą się z uwzględnieniem wzorców wynikających z nowoczesnej koncepcji marketingu. Skutkiem takowego stanu rzeczy są działania marketingowe, przyjmujące charakter „partyzancki” w znikomym stopniu oparte na w pełni profesjonalnych działaniach marketingowych.

5. Zasadniczą determinantą korzystania przez partie polityczne z usług agencji marketingowych nie jest jedynie potrzeba poprawy wskaźników wizerunkowych, a brak technicznych możliwości realizacji elementów 
kampanii we własnym zakresie. Wydaje się zatem, że krajowe partie polityczne na obecnym stadium rozwoju nie potrzebują zaawansowanej metodologicznie i kompleksowej obsługi wizerunkowej realizowanej przez zewnętrznych podwykonawców.

6. W relacjach agencji z formacjami politycznymi istnieje niezwykle niski stopień wzajemnej lojalności. Partie równolegle współpracują z kilkoma agencjami, a zdarza się że te obsługują więcej niż jedną formację w tym samym czasie. Uwarunkowania takie nie stymulują pogłębienia współpracy i świadczą o jej ułomnym charakterze.

\section{Specialized marketing agencies in the market activities of domestic political organizations}

\section{Summary}

The paper tries to identify the role of specialized marketing agencies in the market activities of Polish political parties. It is based on the extensive observations the author carried out with respect to the application of marketing instruments in the political market. The purpose of the text is to demonstrate how political organizations can gain a competitive advantage by permanent cooperation with professional companies offering marketing consulting services. The starting point of these considerations is the concept of Jennifer Lees-Marshment, a researcher into political marketing from New Zealand, who assumes the total market orientation of a modern political organization (Market Oriented Party). According to her, a party should work the way a business does, ceaselessly meeting the needs of its consumer-voters. 
